\title{
Analisis Kinerja Koneksi Jaringan Switch Ethernet pada Local Area Network (LAN)
}

\author{
Abdul Karim ${ }^{* 1}$, Andi Achmadi ${ }^{2}$ \\ ${ }^{1,2}$ Program Studi Teknik Elektro Fakultas Teknik Universitas Muhammadiyah Makassar \\ e-mail: abdulkarim1317@gmail.com*
}

\begin{abstract}
The development of today's telecommunication network is progressing very fast. Various kinds of telecommunication technology facilities continue to be developed so that users can communicate practically, wherever the location of the user the resides. This study aims to find out what processes are running when data packets are sent such as computing and comparing the speed of packet data transmitted (Throughput), packet loss data (Packet Loss), and time delay data transmission from each user used. The method used in this study is to use literature study by taking data in the field with the aim to Calculate the value of Throughput, delay and packet loss of a packet sent by each user in the network Ethernet Switch. From the results of the study obtained Comparison of Througput of each field of work, seen in the financial field has the highest value. While having the lowest Througput value is in the field of news. Comparison of time delay of each field can be in the field of delay news with the fastest time to send data and in the field of finance delay with the longest time in data transmission. The packet loss data analysis of each experiment gets a good average score in each field according to ITU G.114 standard with 0\% percentage.
\end{abstract}

Keywords: Switch Ethernet; throughput; packet loss; delay

\begin{abstract}
Abstrak
Perkembangan jaringan telekomunikasi dewasa ini mengalami kemajuan yang sangat cepat. Berbagai macam fasilitas teknologi telekomunikasi terus dikembangkan agar user dapat melakukan komunikasi secara praktis, di manapun lokasi user tersebut berada. Penelitian ini bertujuan untuk mengetahui apa saja proses yang sedang berjalan ketika paket data dikirim seperti menghitung dan membandingkan kecepatan paket data yang dikirim (throughput), paket data yang hilang (packet loss), dan delay waktu pengiriman data dari setiap user yang digunakan. Metode yang di gunakan pada penelitian ini adalah menggunakan studi literatur dengan mengambil data di lapangan dengan tujuan untuk menghitung nilai throughput, delay dan packet loss suatu paket yang dikirim oleh setiap user dalam jaringan Switch Ethernet. Dari hasil penelitian didapatkan Perbandingan Througput dari setiap bidang kerja, terlihat pada Bidang Keuangan memiliki nilai tertinggi sedangkan yang memiliki nilai throughput terendah berada pada Bidang Berita. Perbandingan waktu delay dari setiap bidang didapatkan pada Bidang Berita delay dengan waktu tercepat mengirim data dan pada Bidang Keuangan delay dengan waktu terlama dalam pengiriman data. Analisa packet loss data dari setiap percobaan mendapatkan nilai rata-rata yang baik di setiap bidang sesuai standar ITU G.114 dengan persentase $0 \%$.
\end{abstract}

Kata kunci: Switch Ethernet, throughput, packet loss, delay

\section{Pendahuluan}

Perkembangan jaringan pada era telekomunikasi dewasa ini mengalami kemajuan yang sangat cepat. Berbagai macam fasilitas teknologi telekomunikasi terus dikembangkan agar user dapat melakukan komunikasi secara praktis, di manapun lokasi user tesebut berada. Komunikasi dapat terjalin, baik di dalam area yang kecil seperti gedung-gedung, sekolah, perkantoran, komunikasi antar gedung, hingga komunikasi dalam satu kota. Untuk membangun suatu komunikasi di area-area yang tidak begitu luas, dapat digunakan jaringan Local Area Network (LAN). LAN digunakan untuk mentransfer data antara PC, workstation, mainframe, dan data peripheral. Salah satu cara untuk memperbaiki performansi end-user adalah dengan 
membagi single segment LAN yang luas ke dalam segmen-segmen LAN yang lebih kecil, yang disebut "microsegment". Oleh karena itu menggunakan perangkat switch agar dapat membagi single segment LAN yang luas ke dalam beberapa segmen. Salah satu teknologi LAN yang diimplementasikan dengan switch adalah Ethernet.

Maraknya penggunaan Switch Ethernet pada sistem komunikasi real-time pada perusahaan LPP TVRI SULSEL mengakibatkan tuntutan keamanan dan pemakaian bandwidth yang optimal dari pengiriman frame pada jaringan tersebut apalagi dengan kegiatan komunikasi data antar sub bagian kerja. Dengan kata lain, dalam satuan unit waktu, switch harus mampu memproses sejumlah paket yang ditransmisikan oleh entitas-entitas yang bersebelahan dan sanggup menyediakan kapasitas bandwidth yang cukup besar untuk mensupport alamat trafik agar sampai ke tujuan. Quality of Service (Qos) merupakan termonologi yang digunakan untuk mendefinisikan kemampuan suatu jaringan untuk menyediakan tingkat jaminan layanan yang berbeda-beda. Qos terbagi dalam beberapa bagian berdasarkan parameternya, yaitu: throughput, packet loss, dan delay.

\section{Metode Penelitian}

Tempat pelaksanaan penelitian dilakukan di kantor LPP TVRI SULSEL dengan kasus yaitu analisis kinerja koneksi jaringan Switch Ethernet pada Local Area Network (LAN). Variabel yang digunakan untuk menentukan nilai throughput, packet loss, dan delay yaitu:

- Data dari hasil percobaan dari setiap user

- Data topologi yang digunakan user yang diteliti.

Penelitian ini menggunakan studi literatur dengan mengambil data di lapangan dengan tujuan untuk menghitung throughput, delay dan packet loss suatu paket yang dikirim dalam jaringan Switch Ethernet. Penelitian ini menggunakan teknik pengambilan data langsung pada setiap user yang digunakan untuk melakukan percobaan pengiriman data. Adapun data-data yang diperlukan dalam penelitian ini adalah :

- Data nilai Throughput setiap user

- Data nilai Packet Loss setiap user

- Data nilai Delay setiap user

- Jenis topologi yang digunakan pada setiap bidang kerja dalam penelitian

Untuk menentukan nilai throughput, packet loss, dan delay digunakan masing-masing Persamaan (1), (2) dan (3) berikut ini:

$$
\text { Throughput }=\frac{\text { Paket data diterima }}{\text { Lama pengamatan }}
$$

$$
\begin{gathered}
\text { Packet Loss }=\frac{(\text { Paket dikirim-paket yang diterima }) \times 100 \%}{\text { Paket data yang dikirim }} \\
\text { Delay }=\frac{\text { Packet length }}{\text { Link bandwidth }}
\end{gathered}
$$

\section{Hasil dan diskusi}

Pada bab ini akan dibahas mengenai menentukan nilai throughput, packet loss, dan delay disetiap bidang kerja. Untuk menghubungkan dari PC user dengan Switch Ethernet, digunakan kabel UTP dan memasang IP address di setiap PC user.

Tabel 1. IP address user

\begin{tabular}{ccc}
\hline Komputer & IP address & Port Switch \\
\hline Bidang Program & 192.168 .251 .10 & 1 \\
Bidang Berita & 192.168 .251 .20 & 2 \\
Bidang Teknik & 192.168 .251 .30 & 3 \\
Bidang Keuangan & 192.168 .251 .40 & 4 \\
Bidang Umum dan SDM & 192.168 .251 .50 & 5 \\
\hline
\end{tabular}




\subsection{Analisis Data Throughput}

Throughput merupakan kecepatan transfer data efektif, yang diukur dalam bps. Throughput merupakan jumlah total kedatangan paket yang sukses yang diamati pada tujuan selama interval waktu tertentu oleh durasi interval waktu tersebut. Data throughput didapatkan dengan cara melihat data statistik pada Wireshark. Berikut contoh cara pengambilan data throughput.

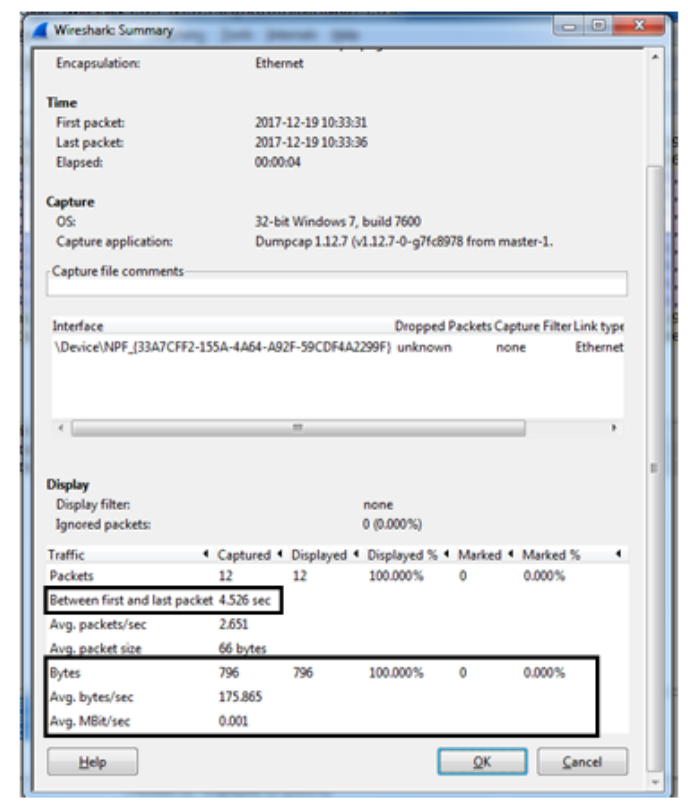

Gambar 1. Data umtuk perhitungan throughput (Sumber: LPP TVRI SULSEL)

Dari data statistik tersebut, dilakukan percobaan di setiap bidang kerja dengan menggunakan persamaan rumus throughput dan hasilnya dapat dilihat pada tabel berikut.

Tabel 2. Analisa data throughput

\begin{tabular}{crrr}
\hline Komputer & $\begin{array}{c}\text { Paket yang } \\
\text { diterima (byte) }\end{array}$ & $\begin{array}{c}\text { Lama } \\
\text { pengamatan }(s)\end{array}$ & $\begin{array}{c}\text { Throughput } \\
\text { (byte/s) }\end{array}$ \\
\hline Bidang Program & 48733370 & 125,902 & 387073,8352 \\
Bidang Berita & 205001471 & 132,428 & 548022,103 \\
Bidang Teknik & 52842000 & 136,517 & 387072,6723 \\
Bidang Keuangan & 161020776 & 142,639 & 1128869,215 \\
Bidang Umum dan SDM & 146808887 & 130,063 & 1128752,12 \\
\hline
\end{tabular}

Pada tabel 2 terlihat throughput pada Bidang Program dengan nilai 387073,8352 byte/s sedangkan pada Bidang Berita throughput yang didapatkan adalah 548022,103 lebih tinggi dari nilai di Bidang Program. Pada Bidang Teknik nilai throughput yang didapatkan adalah 387072,6723 byte/s dan pada Bidang Keuangan 1128869,215 byte/s, nilainya tidak terlalu jauh dengan Bidang Umum \& SDM dengan nilai throughput 1128752,12 byte/s

\subsection{Analisis data packet loss}

Packet loss, merupakan suatu parameter yang menunjukkan jumlah total paket yang hilang, dapat terjadi karena collision atau tabrakan antar paket dan congestion atau penuhnya trafik data pada jaringan. Umumnya perangkat jaringan memiliki buffer untuk menampung data yang diterima. Jika terjadi antrian yang cukup lama, buffer akan penuh dan data baru tidak akan diterima.

Dari penangkapan data yang telah dilakukan dengan Wireshark maka didapatkan packet loss dengan cara menghitung menggunakan persamaan Persamaan (2). Berikut contoh cara pengambilan data packet loss. 


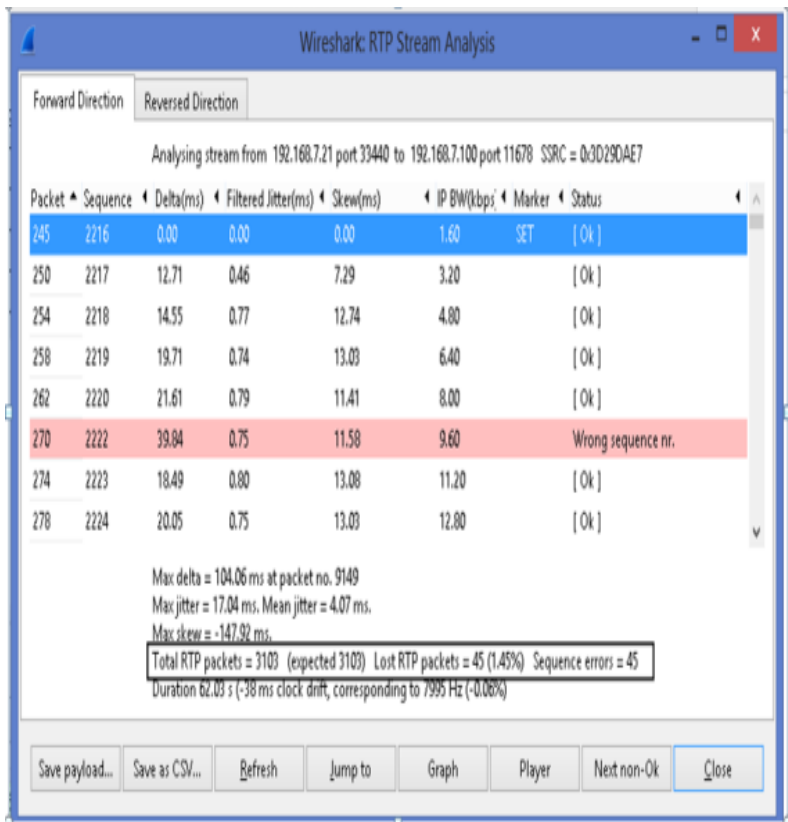

Gambar 2. Data perhitungan packet loss (Sumber: LPP TVRI SULSEL)

Dari melihat contoh pengambilan data statistik tersebut, maka dilakukan percobaan di setiap bidang kerja dengan menggunakan aplikasi Wireshark dengan Persamaan (2) dan hasilnya dapat dilihat pada tabel 3.

Tabel 3. Analisa data packet loss

\begin{tabular}{ccccc}
\hline Komputer & $\begin{array}{c}\text { Packet } \\
\text { dikirim }\end{array}$ & $\begin{array}{c}\text { Packet } \\
\text { diterima }\end{array}$ & $\begin{array}{c}\text { Total } \\
\text { packet }\end{array}$ & $\begin{array}{c}\text { Packet loss } \\
(\%)\end{array}$ \\
\hline Bidang Program & 40352,2 & 40352,2 & 40352,2 & 0 \\
Bidang Berita & 228000,2 & 228000,2 & 228000,2 & 0 \\
Bidang Teknik & 44508 & 44508 & 44508 & 0 \\
Bidang Keuangan & 106718 & 106718 & 106718 & 0 \\
Bidang Umum dan SDM & 45908,6 & 45908,6 & 45908,6 & 0 \\
\hline
\end{tabular}

Pada tabel 3 terlihat pada semua bagian bidang kerja yang ada tidak mengalami gangguan dalam melakukan pengiriman paket data dengan presentase $0 \%$. Packet loss yang didapatkan semua bidang kerja sangat bagus sesuai dengan standar ITU G.114.

\subsection{Analisis data delay}

Delay adalah waktu yang dibutuhkan data untuk menempuh jarak dari asal menuju ke tujuan. Delay dapat dipengaruhi oleh jarak, media fisik, atau waktu proses yang lama. Data delay didapatkan dengan cara melihat data statistik pada Wireshark seperti terlihat pada gambar berikut yang merupakan contoh cara pengambilan data delay menggunakan aplikasi Wireshark. 


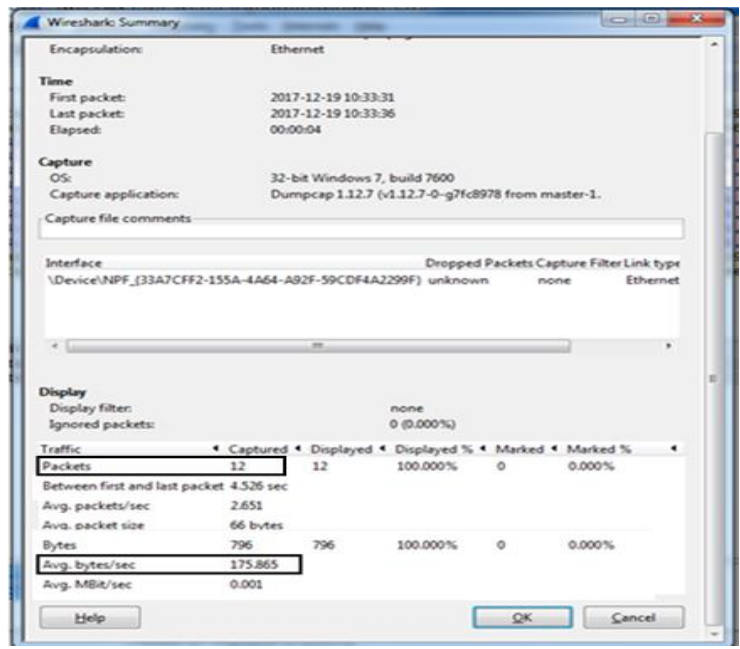

Gambar 3. Data perhitungan delay (Sumber: LPP TVRI SULSEL)

Dari data statistik tersebut, dilakukan percobaan di setiap bidang kerja dengan menggunakan persamaan rumus delay dan hasilnya dapat dilihat pada tabel berikut.

Tabel 4. Analisa data delay

\begin{tabular}{cccc}
\hline Komputer & $\begin{array}{c}\text { Link bandwidth } \\
\text { (byte/s) }\end{array}$ & $\begin{array}{c}\text { Packet length } \\
\text { (byte) }\end{array}$ & Delay (ms) \\
\hline Bidang Program & 329,211 & 451 & 1,36 \\
Bidang Berita & 215,289 & 278 & 1,27 \\
Bidang Teknik & 345,198 & 529 & 1,53 \\
Bidang Keuangan & 243,578 & 389 & 1.59 \\
Bidang Umum dan SDM & 290,230 & 430 & 1,48 \\
\hline
\end{tabular}

Pada tabel 4 delay pada Bidang Program adalah 1,36 ms sedangkan pada Bidang Berita delay yang didapatkan sebesar $1,27 \mathrm{~ms}$ lebih rendah delay dengan waktu terpendek dalam pengiriman data. Pada Bidang Teknik memiliki nilai delay sebesar 1,53 ms dan naik lagi pada Bidang Keuangan dengan delay 1,59 ms kemudian turun pada bidang umum \& SDM yaitu $1,48 \mathrm{~ms}$.

\section{Kesimpulan}

Berdasarkan hasil penelitian yang dilakukan dapat disimpulkan bahwa analisa packet loss data yang diperlihatkan aplikasi Wireshark efektif dari setiap percobaan mendapatkan nilai rata-rata yang baik di setiap bidang sesuai standar ITU G.114. Paket data yang hilang yang di perlihatkan dengan nmenggunakan Wireshark tidak ada paket data yang hilang dan didapatkan dengan persentase nilai $0 \%$. Perbandingan throughput dari setiap bidang kerja, terlihat pada Bidang Keuangan memiliki nilai tertinggi yaitu 1128869,215 byte/s. Sedangkan yang memiliki nilai throughput terendah berada pada Bidang Berita dengan nilai 548022,103 byte/s. Perbandingan waktu delay dari setiap bidang didapatkan pada Bidang Berita memiliki nilai 1,27 ms delay dengan waktu tercepat mengirim data dan pada Bidang Keuangan memiliki nilai 1,59 ms.

\section{Referensi}

[1] A. B. Forouzan, Data communications \& networking (sie). Tata McGraw-Hill Education, 2007.

[2] T. Chandra, "Pemanfaatan Jaringan Komputer pada Laboratorium SMK Dr. Sjahrir Medan," J. TIMES, vol. 3, no. 1, 2014.

[3] N. W. Budiono, "Konfigurasi Dasar Cisco Switch." 2005.

[4] S. P. Toago, A. Alamsyah, and A. Amir, "Perancangan Jaringan Fiber to the Home (Ftth) Berteknologi Gigabit Passive Optical Network (Gpon) Di Perumahan Citraland Palu," Mektrik, vol. 1, no. 1.

[5] R. Wulandari, "Analisis QoS (Quality of Service) Pada Jaringan Internet (Studi Kasus: 
UPT Loka Uji Teknik Penambangan Jampang Kulon-LIPI)," J. Tek. Inform. dan Sist. Inf., vol. 2, no. 2, 2016.

[6] Insanudin, "Rancangan Jaringan Local Area Network Berbasis Windows Sekolah Menengah Pertama (SMP) Negeri 1 Kerjo," IJNS - Indones. J. Netw. Secur., vol. 2, no. 3, Mar. 2013. 